\title{
PROGRAM ONLINE LEARNING SEBAGAI FAKTOR PENUNJANG KEUNGGULAN KOMPETITIF BINUS UNIVERSITY
}

\author{
Johan Muliadi Kerta; Ronny Andrian \\ Jurusan Sistem Informasi, Fakultas Ilmu Komputer, Binus University \\ Jl. KH. Syahdan No. 9, Palmerah, Jakarta Barat 11480 \\ johanmk@binus.ac.id
}

\begin{abstract}
Online learning has become a way to improve efficiency in the learning process without reducing the quality of learning itself. Colleges that run it hope that the program becomes an attraction for prospective students, especially those with limitation to follow the regular program. The goal of this research was to find out whether Binus Online Learning Program has any influence to the competitive advantage of Binus University. Data were compiled by distributing questionnaires to 100 respondents consist of the students and lecturers on Binus Online Learning Program. This thesis is based on a quantitative methodology to gather and analyze the data to find out if they were any correlation between Online Learning Program and the competitive advantage of Binus University. It can be concluded that there are some positive and significant influences of Online Learning Program to the competitive advantage of Binus University. Therefore, promoting and developing Online Learning Program will increase the competitive advantage of Binus University, and cover the target market which regular programs do not.
\end{abstract}

Keywords: online learning, competitive advantage, information system.

\begin{abstract}
ABSTRAK
Pembelajaran online telah menjadi satu cara meningkatkan efisiensi proses pembelajaran tanpa mengurangi kualitas dari pembelajaran itu sendiri. Perguruan tinggi yang menjalankannya berharap agar program ini menjadi suatu daya tarik bagi calon mahasiswa, khususnya yang memiliki keterbatasan untuk mengikuti program regular. Tujuan penelitian ini adalah mengetahui adakah pengaruh antara Program Online Learning dengan keunggulan kompetitif Binus University. Penelitian ini menggunakan metode kuantitatif. Data dikumpulkan dengan menyebarkan kuesioner kepada 100 responden yang terdiri dan mahasiswa dan dosen program Binus Online Learning. Dari hasil penelitian disimpulkan bahwa terdapat pengaruh yang positif dan signifikan pada program Online Learning terhadap keunggulan kompetitif Binus University. Pengaruh ini menunjukkan bahwa kedua variabel ini mempunyai hubungan kausalitas. Oleh karena itu, keunggulan kompetitif Binus University dapat ditingkatkan dengan cara meningkatkan Program Online Learning yang efektif dan mampu menjangkau target pasar di kalangan karyawan dan ibu rumah tangga yang masih sulit dijangkau oleh program reguler.
\end{abstract}

Kata kunci: pembelajaran online, keunggulan kompetitif, sistem informasi. 


\section{PENDAHULUAN}

Arus globalisasi mendorong perguruan tinggi untuk semakin mampu mengembangkan dirinya secara cermat, cepat dan tepat, dalam menyikapi berbagai perubahan, terutama perubahan yang timbul sebagai akibat semakin berkembangnya sistem pendidikan tinggi dan tuntutan otonomi perguruan tinggi. Disamping itu, perguruan tinggi diharapkan mampu meningkatkan peran strategisnya dalam proses kehidupan sosial, ekonomi, politik dan budaya di lingkungan masyarakat, bangsa dan negara. Perguruan Tinggi tidak hanya dituntut menghasilkan sumber daya manusia yang berkualitas dan sesuai dengan kebutuhan pembangunan, namun harus pula mampu menguasai, menerapkan dan mengembangkan sains dan teknologi informasi (IT) yang sekaligus menjadi sebagai faktor penunjang yang penting untuk meningkatkan keunggulan kompetitif perguruan tinggi tersebut (Benson, et.al., p.37)

Penyelenggaraan pendidikan yang tampak semakin berkembang tidak hanya menjadi indikator kemajuan perguruan tinggi dalam menyelenggarakan program-program pendidikan, akan tetapi menunjukkan pula sejumlah indikator kecenderungan dunia pendidikan tinggi yang layak dicermati, terlebih dalam era globalisasi yang sarat dengan arus informasi, keterbukaan dan persaingan yang semakin tinggi. Indikator-indikator kecenderungan dunia perguruan tinggi yang dimaksud seperti adanya sejumlah perguruan tinggi swasta yang penyelenggaraan programnya menyebar sampai ke sejumlah lokasi strategis selain di pusat ibukota dan aktivitas perkuliahannya pun tak lagi terpusat hanya di kampus sebagaimana lazimnya, tetapi sebagian diantaranya ada yang digelar di hotel, gedung pemerintahan, gedung fasilitas umum, dan melalui komputer, notebook atau smartphone dengan memanfaatkan akses internet (Dabbagh, Brenda, 2004). Kemasan program yang ditawarkan pun lebih praktis, baik dari segi materi, waktu maupun dari segi teknis perkuliahan dengan melandaskan strategi manajemennya yang berbasis entrepreneurship, cost efficiency dan competitive advantages.

Binus University telah mensikapi dan mencermati tuntutan dan kebutuhan pasar pendidikan yang semakin berkembang, terlebih lagi dengan kemajuan teknologi informasi yang semakin pesat. Dalam konteks ini, pemanfaatan teknologi informasi (IT) menjadi sangat penting sebagai salah sebagai faktor krusial untuk menghadapi tuntutan dan tantangan pesaingan di dunia pendidikan. Salah satu indikator pemanfaatan IT dalam dunia pendidikan adalah mengaplikasikan pembelajaran yang berbasis teknologi (e-learning) dengan Program Online Learning sebagai penunjang keunggulan kompetitifnya (competitive advantages).

Program Online Learning merupakan metode pembelajaran baru yang dikembangkan oleh Binus University sejak tahun 2008 sebagai media belajar online bagi individu yang ingin belajar dan mengembangkan diri tanpa harus terikat dengan jadwal dan tempat tertentu. Metode ini sangat cocok untuk mahasiswa yang saat ini juga berstatus sebagai perkerja profesional dan wiraswasta bahkan ibu rumah tangga yang ingin melanjutkan studi S1 tanpa terhambat dengan waktu dan tempat. Aktifitas belajar dirancang untuk fokus pada karakteristik mahasiswa dan untuk mendapatkan hasil yang berkualitas dengan bimbingan dosen akademisi maupun praktisi yang berpengalaman, menjadikan Binus Online Learning dapat mempercepat karir mahasiswa.

Keunggulan dari program online learning ini adalah sifat perkuliahannya yang sangat fleksibel. Dalam kegiatan belajar, mahasiswa dapat melakukan interaksi dengan dosen tanpa ada batasan waktu dan tempat. Kehadiran dalam tatap muka di ruang kelas tetap akan dilakukan, tetapi terbatas pada kegiatan yang bersifat pembahasan kasus, diskusi pemantapan pemahaman materi kuliah, dan pada saat mengikuti ujian. Selain itu, kualitas lulusan dari program Binus Online Learning ini adalah kualitas lulusannya yang tidak kalah dengan mahasiswa yang mengikuti kegiatan perkuliahan pada umumnya. Hal ini dimungkinkan program Binus Online Learning menggunakan Learning Management System (LMS) yang terintegrasi untuk membangun jaringan interaksi antara 
mahasiswa dengan mahasiswa, mahasiswa dengan dosen dan mahasiswa dengan pembimbing akademis (Website BINUS Online Learning).

Namun demikian, yang perlu disikapi oleh Binus University adalah apakah penyelenggaraan online learning ini dapat meningkatkan daya saingnya, atau hanya sebagai salah satu program tambahan yang tidak memiliki dampak signifikan terhadap visi dan misi yang dituju, yaitu sebagai Universitas kelas dunia (Website BINUS University, Visi dan Misi). Selanjutnya tujuan dari penelitian ini adalah untuk mengetahui apakah terdapat pengaruh antara Program Online Learning dengan keunggulan kompetitif di BINUS University yang berdampak pada peningkatan dalam efisiensi proses pembelajaran secara umum.

\section{METODE}

Metodologi yang digunakan dalam penelitian ini adalah dengan melakukan pengembangan studi kasus (Case Study), dengan memanfaatkan sumber-sumber seperti documentation, archival records, interviews, direct observations, participant-observations, dan physical artifacts (Sekaran, 2003). Berpijak pada kerangka pikir yang terstruktur seperti terlihat pada gambar di bawah ini:

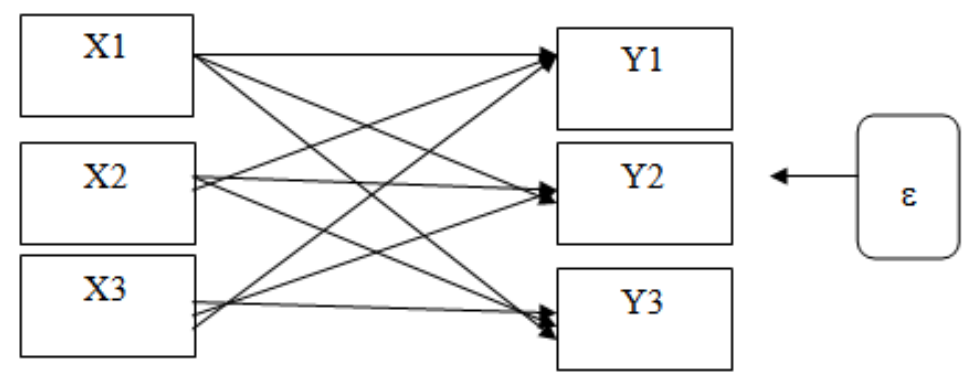

Gambar 1. Kerangka Pikir.

\section{Keterangan gambar:}

$\mathrm{X}$ adalah variabel bebas (independent variable) Program Online Learning yang diposisikan sebagai variabel antecedent.

X1 adalah dimensi Model Pedagogik atau Konstruk dalam variable bebas Program Online Learning. X2 adalah dimensi Strategi Pembelajaran dalam variable bebas Program Online Learning.

$\mathrm{X} 2$ adalah dimensi Teknologi Belajar dalam variable bebas Program Online Learning.

$\mathrm{Y}$ adalah variabel terikat (dependent variable) Competitive Advantage yang diposisikan sebagai variabel konsekuensi.

Y1 adalah dimensi Strategi Keunggulan Biaya dalam varibel terikat Competitive Advantage.

Y2 adalah dimensi Strategi Diferensiasi dalam varibel terikat Competitive Advantage.

Y3 adalah dimensi Strategi Fokus dalam varibel terikat Competitive Advantage.

$\longrightarrow$ adalah $\rho$ YX parameter struktural yang menjadi model pengukuran pengaruh $\mathrm{X}$ terhadap $\mathrm{Y}$.

$\varepsilon$ (epsilon) adalah faktor-faktor lain yang juga turut mempengaruhi $\mathrm{Y}$ tetapi tidak diteliti.

Dengan menggunakan kerangka pikir tersebut dilakukan suatu penelitian yang menguji hubungan antara pelaksanaan Program Online Learning ini dengan tingkat keunggulan kompetitif BINUS University sebagai penyelenggara pendidikan tinggi. Pengujian yang dilakukan adalah Pengujian Validitas, Reliabilitas dan Hipotesis yang telah ditentukan (Sudjana, 2001). Metode pengumpulan data empiris menggunakan kuesioner yang disebarkan kepada dosen dan mahasiswa peserta program ini. 


\section{HASIL DAN PEMBAHASAN}

\section{Hasil Pengujian Persyaratan Analisis}

\section{Pengujian Validitas Instrumen Penelitian (Tabel 1)}

Tabel 1

Hasil Pengujian Validitas Korelasi Instrumen Variabel Penelitian

\begin{tabular}{cccccccc}
\hline No & $\begin{array}{c}\text { Variabel } \\
\mathbf{X}\end{array}$ & $\begin{array}{c}\mathbf{r} \\
\text { tabel }\end{array}$ & Kriteria & No & $\begin{array}{c}\text { Variabel } \\
\mathbf{Y}\end{array}$ & $\begin{array}{c}\mathbf{r} \\
\text { tabel }\end{array}$ & Kriteria \\
\hline 1 & 0,600 & 0,195 & Valid & 1 & 0,667 & 0,195 & Valid \\
\hline 2 & 0,598 & 0,195 & Valid & 2 & 0,611 & 0,195 & Valid \\
\hline 3 & 0,632 & 0,195 & Valid & 3 & 0,548 & 0,195 & Valid \\
\hline 4 & 0,574 & 0,195 & Valid & 4 & 0,588 & 0,195 & Valid \\
\hline 5 & 0,693 & 0,195 & Valid & 5 & 0,682 & 0,195 & Valid \\
\hline 6 & 0,637 & 0,195 & Valid & 6 & 0,666 & 0,195 & Valid \\
\hline 7 & 0,620 & 0,195 & Valid & 7 & 0,647 & 0,195 & Valid \\
\hline 8 & 0,562 & 0,195 & Valid & 8 & 0,440 & 0,195 & Valid \\
\hline 9 & 0,639 & 0,195 & Valid & 9 & 0,652 & 0,195 & Valid \\
\hline 10 & 0,536 & 0,195 & Valid & 10 & 0,584 & 0,195 & Valid \\
\hline 11 & 0,204 & 0,195 & Valid & 11 & 0,614 & 0,195 & Valid \\
\hline 12 & 0,573 & 0,195 & Valid & 12 & 0,661 & 0,195 & Valid \\
\hline
\end{tabular}

Sumber: Diolah dari hasil penelitian.

\section{Hasil Pengukuran dan Pengujian Hipotesis}

Pengaruh Model Pedagogik atau Konstruk, Strategi Pembelajaran dan Teknologi Belajar secara bersama-sama terhadap Competitive Advantage

Dari hasil pengukuran statistik persamaan regresi diketahui besarnya pengaruh Model Pedagogik atau Konstruk (X1), Strategi Pembelajaran (X2) dan Teknologi Belajar (X3) secara bersama-sama terhadap Competitive Advantage di Binus University sebagai berikut (Tabel 2-6):

Tabel 2

Nilai Koefisien Korelasi dan Determinasi $X_{1}, X_{2} X_{3}$ dengan $Y$

\begin{tabular}{|l|r|r|r|r|}
\hline Model & \multicolumn{1}{|c|}{ R } & R Square & $\begin{array}{c}\text { Adjusted } \\
\text { R Square }\end{array}$ & $\begin{array}{r}\text { Std. Error of } \\
\text { the Estimate }\end{array}$ \\
\hline 1 & $.868^{\mathrm{a}}$ & .754 & .746 & 3.94338 \\
\hline
\end{tabular}

a. Predictors: (Constant), Teknologi Belajar, Strategi Pembelajaran, Model Pedagogik atau Konstruk

Berdasarkan Tabel 2 di atas, koefisien korelasi antara Model Pedagogik atau Konstruk (X1), Strategi Pembelajaran (X2) dan Teknologi Belajar (X3) secara bersama-sama dengan Competitive Advantage (Y) di Binus University adalah 0,868. Nilai tersebut dikonsultasikan ke dalam nilai tabel $r$ harga kritik produk moment dengan taraf signifikansi $5 \%$ pada $\mathrm{db}=\mathrm{N}$, maka diperoleh bahwa $\mathrm{r}$ hitung lebih besar daripada $r$ tabel $(0,868>0,195)$. Hal ini menunjukkan hubungan yang erat antara Model Pedagogik atau Konstruk (X1), Strategi Pembelajaran (X2) dan Teknologi Belajar (X3) secara bersama-sama dengan Competitive Advantage (Y) di Binus University. 
Sedangkan angka $\mathrm{R}$ square (koefisien determinasi) yang diperoleh adalah 0,754, yang berarti sebesar 75,4\% dari keragaman Competitive Advantage di Binus University dapat dijelaskan oleh Model Pedagogik atau Konstruk (X1), Strategi Pembelajaran (X2) dan Teknologi Belajar (X3). Sedangkan sisanya $24,6 \%$ oleh faktor-faktor lain.

Berdasarkan Tabel 3 di bawah ini, persamaan garis regresi X1, X2, dan X3 terhadap Y adalah $\hat{\mathrm{Y}}=6,721+1,599 \mathrm{X}_{1}+0,374 \mathrm{X}_{2}+0,570 \mathrm{X}_{3}$. Dalam persamaan regresi berganda tersebut diketahui bahwa nilai regresi $\left(b_{1}\right)$ sebesar 1,599 , nilai regresi $\left(b_{2}\right)$ sebesar 0,374 dan nilai regresi $\left(b_{3}\right)$ sebesar 0,570 yang merupakan besarnya pengaruh Model Pedagogik atau Konstruk (X1), Strategi Pembelajaran (X2) dan Teknologi Belajar (X3) secara bersama-sama terhadap Competitive Advantage (Y) di Binus University. Karena nilai regresi tersebut positif, apabila terjadi peningkatan pada Model Pedagogik atau Konstruk (X1), Strategi Pembelajaran (X2) dan Teknologi Belajar (X3) secara bersama-sama, maka akan diimbangi dengan peningkatan pada Competitive Advantage di Binus University. Dari persamaan regresi tersebut, dapat dilihat bahwa ternyata pengaruh Model Pedagogik atau Konstruk terhadap Competitive Advantage di Binus University lebih besar daripada pengaruh Strategi Pembelajaran dan Teknologi Belajar.

Tabel 3

Persamaan Garis Regresi $X_{1}, X_{2}, X_{3}$ terhadap $Y$

\begin{tabular}{|c|c|c|c|c|c|c|}
\hline \multirow[b]{2}{*}{ Model } & & \multicolumn{2}{|c|}{$\begin{array}{l}\text { Unstandardized } \\
\text { Coefficients }\end{array}$} & \multirow{2}{*}{$\begin{array}{c}\text { Standardized } \\
\text { Coefficients }\end{array}$} & \multirow[b]{2}{*}{$\mathrm{t}$} & \multirow[b]{2}{*}{ Sig. } \\
\hline & & B & Std. Error & & & \\
\hline \multirow[t]{4}{*}{1} & (Constant) & 6.721 & 2.259 & & 2.975 & .004 \\
\hline & $\begin{array}{l}\text { Model Pedagogik atau } \\
\text { Konstruk }\end{array}$ & 1.599 & .175 & .632 & 9.121 & .000 \\
\hline & Strategi Pembelajaran & .374 & 147 & 162 & 2.543 & .013 \\
\hline & Teknologi Belajar & .570 & .159 & .211 & 3.578 & .001 \\
\hline
\end{tabular}

a. Dependent Variable: Competitive Advantage

Selanjutnya, uji hipotesis pengaruh Model Pedagogik atau Konstruk (X1), Strategi Pembelajaran (X2) dan Teknologi Belajar (X3) secara bersama-sama terhadap Competitive Advantage (Y) di Binus University dilakukan dengan membandingkan F hitung dengan F tabel (Tabel 4). Kriteria pengujiannya adalah apabila $\mathrm{F}$ hitung $>\mathrm{F}$ tabel, $\mathrm{H}_{0}$ ditolak dan $\mathrm{H}_{1}$ diterima. Sebaliknya apabila $\mathrm{F}$ hitung $<\mathrm{F}$ tabel, $\mathrm{H}_{0}$ diterima dan $\mathrm{H}_{1}$ ditolak.

Pada Tabel 4 di bawah ini terlihat bahwa nilai $\mathrm{F}$ hitung yang diperoleh dalam analisis data pengaruh Model Pedagogik atau Konstruk (X1), Strategi Pembelajaran (X2) dan Teknologi Belajar (X3) secara bersama-sama terhadap Competitive Advantage (Y) di Binus University adalah 98,136. Nilai $\mathrm{F}$ tabel dengan taraf tingkat signifikansi $5 \%(\alpha=0,025)$ dan $\mathrm{v}_{1}=\mathrm{k}=2, \mathrm{v}_{2}=\mathrm{n}-\mathrm{k}-1=100-2-1=97$ adalah 3,34. Karena $\mathrm{F}$ hitung $>\mathrm{F}$ tabel $(98,136>3,34), \mathrm{H}_{0}$ ditolak dan $\mathrm{H}_{1}$ diterima. Dengan demikian terdapat pengaruh Model Pedagogik atau Konstruk (X1), Strategi Pembelajaran (X2) dan Teknologi Belajar (X3) secara bersama-sama terhadap Competitive Advantage (Y) di Binus University.

Persamaan garis regresi yang diperoleh berdasarkan Tabel 5 di bawah ini adalah $\hat{Y}=6,721+$ $1,599 \mathrm{X}_{1}+0,374 \mathrm{X}_{2}+0,570 \mathrm{X}_{3}$. Dalam persamaan regresi berganda tersebut diketahui bahwa nilai regresi $\left(b_{1}\right)$ sebesar 1,599 , nilai regresi $\left(b_{2}\right)$ sebesar 0,374 dan nilai regresi $\left(b_{3}\right)$ sebesar 0,570 yang merupakan besarnya pengaruh Model Pedagogik atau Konstruk (X1), Strategi Pembelajaran (X2) dan Teknologi Belajar (X3) secara bersama-sama terhadap Competitive Advantage (Y) di Binus University. Karena nilai regresi tersebut positif, apabila terjadi peningkatan pada Model Pedagogik atau Konstruk (X1), Strategi Pembelajaran (X2) dan Teknologi Belajar (X3) secara bersama-sama akan diimbangi dengan peningkatan pada Competitive Advantage di Binus University. Dari persamaan 
regresi tersebut, dapat dilihat bahwa ternyata pengaruh Model Pedagogik atau Konstruk terhadap Competitive Advantage di Binus University lebih besar daripada pengaruh Strategi Pembelajaran dan Teknologi Belajar.

Tabel 4

ANOVA

\begin{tabular}{|c|c|c|c|c|c|c|}
\hline Model & & $\begin{array}{l}\text { Sum of } \\
\text { Squares }\end{array}$ & df & Mean Square & $\mathrm{F}$ & Sig. \\
\hline \multirow[t]{3}{*}{1} & Regression & 4578.134 & 3 & 1526.045 & 98.136 & $.000^{\mathrm{a}}$ \\
\hline & Residual & 1492.826 & 96 & 15.550 & & \\
\hline & Total & 6070.960 & 99 & & & \\
\hline
\end{tabular}

a. Predictors: (Constant), Teknologi Belajar, Strategi Pembelajaran, Model Pedagogik atau Konstruk

b. Dependent Variable: Competitive Advantage

Tabel 5

Persamaan Garis Regresi $X_{1}, X_{2}, X_{3}$ terhadap $Y$

\begin{tabular}{|ll|r|r|r|r|r|}
\hline \multirow{2}{*}{ Model } & \multicolumn{2}{|c|}{$\begin{array}{c}\text { Unstandardized } \\
\text { Coefficients }\end{array}$} & $\begin{array}{c}\text { Standardized } \\
\text { Coefficients }\end{array}$ & & \\
\cline { 2 - 5 } & \multicolumn{1}{|c|}{ B } & Std. Error & \multicolumn{2}{|c|}{ Beta } & \multicolumn{1}{c|}{ S } & \multicolumn{1}{c|}{ Sig. } \\
\hline 1 & (Constant) & 6.721 & 2.259 & & 2.975 & .004 \\
& Model Pedagogik atau & 1.599 & .175 & .632 & 9.121 & .000 \\
& Konstruk & .374 & .147 & .162 & 2.543 & .013 \\
& Strategi Pembelajaran & .570 & .159 & .211 & 3.578 & .001 \\
\hline
\end{tabular}

a. Dependent Variable: Competitive Advantage

Selanjutnya, uji hipotesis pengaruh Model Pedagogik atau Konstruk (X1), Strategi Pembelajaran (X2) dan Teknologi Belajar (X3) secara bersama-sama terhadap Competitive Advantage (Y) di Binus University dilakukan dengan membandingkan $\mathrm{F}$ hitung dengan $\mathrm{F}$ tabel. Kriteria pengujiannya adalah apabila $\mathrm{F}$ hitung $>\mathrm{F}$ tabel, $\mathrm{H}_{0}$ ditolak dan $\mathrm{H}_{1}$ diterima. Sebaliknya apabila $\mathrm{F}$ hitung $<\mathrm{F}$ tabel, $\mathrm{H}_{0}$ diterima dan $\mathrm{H}_{1}$ ditolak.

Nilai F hitung yang diperoleh dalam analisis data pengaruh Model Pedagogik atau Konstruk (X1), Strategi Pembelajaran (X2) dan Teknologi Belajar (X3) secara bersama-sama terhadap Competitive Advantage (Y) di Binus University adalah 98,136 (Tabel 6). Nilai $\mathrm{F}$ tabel dengan taraf tingkat signifikansi $5 \%(\alpha=0,025)$ dan $\mathrm{v}_{1}=\mathrm{k}=2, \mathrm{v}_{2}=\mathrm{n}-\mathrm{k}-1=100-2-1=97$ adalah 3,34. Karena $\mathrm{F}$ hitung $>\mathrm{F}$ tabel $(98,136>3,34), \mathrm{H}_{0}$ ditolak dan $\mathrm{H}_{1}$ diterima. Dengan demikian terdapat pengaruh Model Pedagogik atau Konstruk (X1), Strategi Pembelajaran (X2) dan Teknologi Belajar (X3) secara bersama-sama terhadap Competitive Advantage (Y) di Binus University.

Tabel 6

ANOVA $^{\mathrm{b}}$

\begin{tabular}{|ll|c|r|r|r|c|}
\hline \multicolumn{2}{|c|}{} & Sum of & & & & \\
\hline 1 & Squares & df & Mean Square & \multicolumn{1}{c|}{$\mathrm{F}$} & \multicolumn{1}{c|}{ Sig. } \\
\hline & Regression & 4578.134 & 3 & 1526.045 & 98.136 & $.000^{\mathrm{a}}$ \\
& Residual & 1492.826 & 96 & 15.550 & & \\
& Total & 6070.960 & 99 & & & \\
\hline
\end{tabular}

a. Predictors: (Constant), Teknologi Belajar, Strategi Pembelajaran, Model Pedagogik atau Konstruk

b. Dependent Variable: Competitive Advantage 


\section{SIMPULAN}

Berdasarkan hasil pengukuran dan pengujian hipotesis, dapat disimpulkan bahwa terdapat pengaruh positif dan signfikan Program Online Learning terhadap Competitive Advantage di Binus University. Adanya pengaruh ini menunjukkan bahwa apabila Program Online Learning meningkat atau ditingkatkan maka peningkatan tersebut akan disertai dengan peningkatan Competitive Advantage di Binus University. Simpulan ini menunjukkan bahwa di antara variabel bebas Program Online Learning dengan variabel terikat Competitive Advantage di Binus University terbentuk suatu dinamika hubungan kausalitas, karena itu, peningkatan Competitive Advantage di Binus University dapat ditingkatkan dengan cara meningkatkan Program Online Learning yang efektif.

Dengan demikian, hasil penelitian ini dapat dijadikan landasan untuk menyatakan bahwa peningkatan Competitive Advantage di Binus University dipengaruhi oleh Program Online Learning. Hubungan antar variabel ini dapat dinyatakan sebagai hubungan kausalitas yang menempatkan Program Online Learning sebagai variabel antecedent (yang mendahului, sebab) dan Competitive Advantage di Binus University sebagai variabel konsekuensi (fenomena, akibat). Dengan kenyataan ini maka layak dinyatakan bahwa Competitive Advantage di Binus University dapat meningkat atau ditingkatkan dengan cara meningkatkan values dari Program Online Learning.

\section{DAFTAR PUSTAKA}

Benson, Robert J. et al. (2004). From Business Strategy to IT Action. New Jersey: John Wiley \& Sons.

Bina Nusantara. (n.d.). Visi dan Misi Bina Nusantara. Diakses 17 Juni 2010 dari http://www.binus.edu/About.BINUS/Vision.and.Mission/English.

Binus University. (n.d.). Binus Online Learning. Diakses 17 Juni 2010 dari http://www.online.binus.ac.id/default.aspx

Dabbagh, Nada \& Bannan-Ritland, Brenda. (2004). Online Learning: Concepts, Strategies, and Application. New Jersey: Prentice Hall.

Sekaran, U. (2003). Research Methods for Business: A Skill-Building Approach. New Jersey: John Wiley \& Sons.

Sudjana. (2001). Metode Statistika. Bandung: Tarsito. 